\title{
FROM STONE TO NORWEGIAN WOOD
}

\author{
KNUT JONAS ESPEDAL \\ Deptartment of Industrial Economics, Risk Management and Planning, University of Stavanger, Norway.
}

\begin{abstract}
Throughout the centuries, nearly all signal buildings on the European continent have been built in masonry or concrete - in harsh, 'stone-like' materials. Norway differs remarkably from this main trend. We see that the European examples of stone architecture are largely reinterpreted in Norway as architecture in wood. The keywords are climate, economy, knowledge and tradition. Climate: Wood provides significantly better thermal insulation than brick, stone and concrete. Economy: With the exception of the last 50 years, Norway has been a poor country on the edge of Europe; therefore, there were rarely sufficient finances to build resource-intensive, magnificent buildings in stone or masonry. Knowledge and tradition: These factors are interrelated; tradition leads to knowledge and knowledge creates tradition. Norway has always had skilled carpenters, joiners and wood carvers from the Viking era until the present day. Despite poverty and distance, Norway was not an isolated and uninformed country; Norwegians have always been a seafaring people who grasped European impulses and style trends and brought them home.

Keywords: building style, buildings in wood, log technique, Norway, stave churches, Viking ships
\end{abstract}

\section{INTRODUCTION}

In this context, the term 'stone' includes all hard 'stone-like' materials - natural stone, brick and concrete.

I will provide a few glimpses of the 1000-year history of Norwegian wood building. The conclusion of my contribution will be, in short, that virtually everything that can be built in stone can also be built in wood. However, one should take into account the fact that the characteristics of wood differ from those of hard materials, and usually this has been taken into consideration. If done skillfully, it will never be a matter of pure copying.

Throughout the centuries, virtually all signal buildings on the European continent has been carried out in masonry or concrete - in harsh, 'stone-like' materials. Norway stands out remarkably from this main trend. To a very large extent, we see that the role models of European stone architecture interpreted the wooden architecture of the tree's terms - and so it must be. We must always respect the character of the wood, and this will be demonstrated in the examples I will show. Although Norway is on the outskirts of Europe, it has, nevertheless, always been a European country and, like the rest of Europe, Norwegians have of course also built in stone. Conversely, we do not find wooden architecture only in Norway but everywhere in Europe, especially in places with a climate similar to that of Norway, for example, in cold upland areas in southern Germany, Austria and Switzerland. Nevertheless, the distribution differed. In Norway, we have built significantly more with wood and less with stone than is otherwise common in Europe and mostly also elsewhere. Norway is second only to Japan, which is the country in the world with the most preserved wooden buildings from before the Reformation [1]. The main reasons for Norwegians building so much with wood can be summarized with the keywords: climate, economy, knowledge and tradition:

- Climate: Wood provides significantly better thermal insulation than brick, stone and concrete. A compact wall in stone/concrete must be around 10 to 15 times thicker than a compact wall in timber to achieve the same thermal insulation capacity, which is important in a 
country where large areas are covered with snow for half the year.

- Economy: With the exception of the last 50 years, Norway has been a poor country on the edge of Europe. There was of course an upper class, but Norway has always been a relatively egalitarian society, and the elite have also been relatively poor compared with the upper classes on the continent. Thus, there were rarely finances to produce resourceintensive magnificent buildings in stone masonry. Wood has always been a cheap and locally produced resource in Norway.

- Knowledge and tradition: These factors are interrelated; tradition leads to knowledge and knowledge creates tradition. Norway has always had skilled carpenters, joiners and wood carvers from the Viking era right up to our present time. Poverty and distance did not mean that Norway was an isolated and uninformed country; from the Viking era to the modern day, Norwegians have always been a seafaring people, who took up European style trends and brought them home. But previously it took quite a long time for the European influences to become rooted in Norway - often several generations.

\section{CITY FIRES AND RECONSTRUCTION IN WOOD}

Before we begin a historical review of the Norwegian building tradition, I will offer an example of the strength of the Norwegian preference for wood - the reality of tradition, skills and cost in real-life terms. We will look at the phenomenon of city fires in Norway.

The old Norwegian towns consisted of dense wooden buildings and were highly susceptible to fires. A google search of fires in the seven largest Norwegian cities, Oslo excepted, over a period from about 1500 to 1905 - around 400 years - found 98 big fires. This represents a city fire in average every four years, and that is very frequent! Yet, they continued to rebuild the cities in wood, time after time.

My Town, Stavanger can be used as an example. Here there was a great fire in the spring of 1860. Two hundred and fifty homes burned down and 2.000 people were left homeless in a city, which at that time had about 14.000 inhabitants. After the fire, both national and local building authorities argued strongly that the new buildings should be erected in masonry. However, an adequate legal framework was lacking, and the central technical authorities faced strong resistance in the presidency, among the carpenters and in the general population. They argued that there were not enough masons, not enough bricks, not enough calcium, the cost was too high, the ground was not strong enough to carry brick houses, brick buildings were not compatible with the city's business life and that the city's structure made it difficult to draw a reasonable limit in respect of which areas should be within and without the masonry enforcement area. Almost all possible arguments to avoid having to build in masonry came into play [2]. Nobody mentioned that there was clay and brickworks in Sandnes, $15 \mathrm{~km}$ away. Nobody said that Stavanger lay on Jæren, which at that time was a completely treeless area. Replanning took place for the fire zone, and the rebuilding started rapidly (this was a time of great herring fishing and the economy was relatively good), and after a few years the firestruck area was rebuilt - with 197 wooden houses and three houses in masonry. They built illegally, they applied for exemptions and they creatively interpreted the applicable building regulations. To push through brick buildings, the government decided that only small houses should be built in wood; larger buildings must be in masonry. Figure 1 shows how these regulations were 'understood'.

'We do not count the lower floor; it's a basement! And of course we measure just up to the eaves - to the highest point on the wall'. 

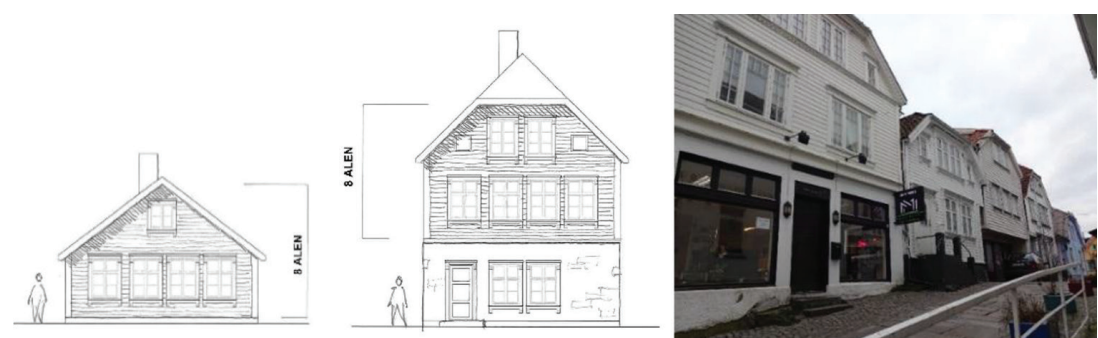

Figure 1: (a) The principle of the law, (b) how the law was interpreted and (c) picture from the area today.

After the fire, we can register a long-lasting discussion between local and central authorities regarding whether the legal building height for timber houses should be 7,8 or 12 alen ( 1 alen $=2$ feet $=62.75 \mathrm{~cm})$, and historian Anders Haaland [1] summarizes the period 1860 1875 as follows: 'An unsuccessful attempt to force a masonry city by building regulations'.

Oslo was not counted in the above mentioned fire statistics, because it introduced a masonry constraint in 1624 - as the only Norwegian town at the time. However, despite this, after 142 years of such rules, in 1766, we still find that only $20 \%$ of Oslo's buildings were solid masonry, while $50 \%$ were in 'rough timbered Danish style' and $30 \%$ in cog joint. In addition to this, there was a rapid growth of suburbs outside the bricked constraint zone. In Oslo they also built illegally, applied for exemptions and used all possible loopholes in the regulations to avoid having to build in masonry [3].

The examples of Stavanger and Oslo show a pattern that we generally find in the stories of reconstruction after fires in all Norwegian cities. One would have thought that the frequency of fires would eventually make people realize that it would be wisest to choose masonry, but it was not so. It seems that anything other than timber was unimaginable to most people.

In 1904, 60\% of Ålesund city burned: 700 houses were razed to the ground; after this disaster, the national authorities finally succeeded in adopting a sufficiently strong masonry enforcement decree in Norwegian cities. If we count the Ålesund fire, as well as some of the fires in Oslo before the masonry constraint was introduced there, we can say that it took over 100 city fires to convince Norwegians that it was wise to build in masonry in dense city centers. And it was the elite, in professions and governments, who were convinced. Most people would certainly have continued to build with wood if they had been allowed.

How to build a timber city in a treeless area? They did not carry in timber; they carried in finished houses. Log houses were built by experienced craftsmen in heavily forested areas. Then the logs were marked; the buildings were dismantled, and the building sets were transported to the sites, where they were placed on finished foundations and rebuilt. Transport was mainly by water: first, floating down to the see and then on boats to the destination. [1] Many of the houses in Stavanger came from Suldal, which is a $70 \mathrm{~km}$ voyage. The transport then meant probably a round journey of about a week. After the fire, we also find newspaper advertisements, stating that log buildings can be delivered from Oslo [2], and that means sailing all around the coast of southern Norway - a longer voyage than the sea route from London to Paris. Long voyages were not unusual at that time, but this still illustrates the importance of tradition and expertise: This is something we can do! This is something we have done before! No problems! Masonry constraint however - problematic! 


\section{THE VIKING SHIPS}

The first credible written records regarding the history of Norway date back to about the year 700 and describe the ancestors of the first Norwegian king, Harald, who united Norway into one kingdom at the Battle of Hafrsfjord in 872. It is unclear as to what is legend and what is true history in these accounts, but research suggests that there was a huge social, cultural and technical leap in development around 800. An important element of this leap was technical, namely the development of the Viking ship. Viking ships were flat-bottomed, fast, easy to handle and very seaworthy. They were resilient and did not head into the waves but moved smoothly along with the rolling so that they withstood the weather extremely well. A part of the secret was that the materials for the hull were not made with an ax or saw but split so that the wood cells' directional structure was not destroyed. Thereby, the materials retained their natural extensibility very well. Viking ships demonstrate excellent understanding of the properties of wood and superb craftsmanship; in addition they were greatly adorned with woodcarvings and with dragon heads at the bow (Fig. 2). In many ways, the Viking age gave Norway the position of a superpower in the early Middle Ages. The Faroe Islands, Orkney, Shetland, the Hebrides, The Isle of Man, Iceland and Greenland were under the rule of the Norwegian king. Moreover, over $50.000 \mathrm{~km}^{2}$ of today's Sweden was Norwegian, and there were Norwegian settlements in America. The Vikings went eastward, far into Russia; they plundered Paris and London, and Viking Gang-Rolf was duke of Normandy. His descendant, Wilhelm won the English throne when he led the Norman army at the Battle of Hastings in 1066. The Viking Expeditions gave Norwegians contact with European civilization, art and culture, including Christianity, and from the mid-1000s, the law, art and monuments are witnesses that Christianity establishes itself as the new faith in the country, and Viking missions as depredations declined. The Viking age lasted for 300 years, from approximately 800 to ca. 1100, but Norway's strong position held for another 200 years until the king died childless in 1319 and the plague struck in 1349. The Black Death hit harder in Norway than in most other countries; it took over 150 years before the population returned to the same numbers as before the plague, and Norway was an inferior fringe for hundreds of years.

Many probably associate Viking raids only with unscrupulous savages, who pillaged and killed, and there are many credible accounts of Viking violent rampage; this is undoubtedly a part of the history, but it is not the whole picture. The fact is that many, perhaps most, Viking voyages were relatively peaceful trading voyages, which brought positive dividends at home and abroad, and this applied not only goods and other material assets, but also to thinking, religion and culture.

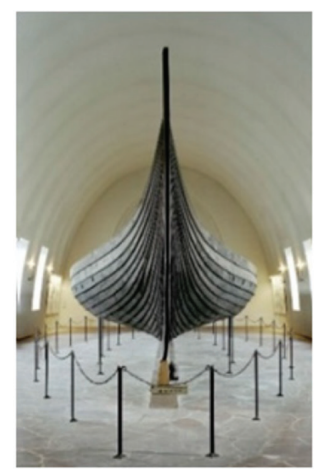

Figure 2: ( $a$ and $b$ ) Viking ship.
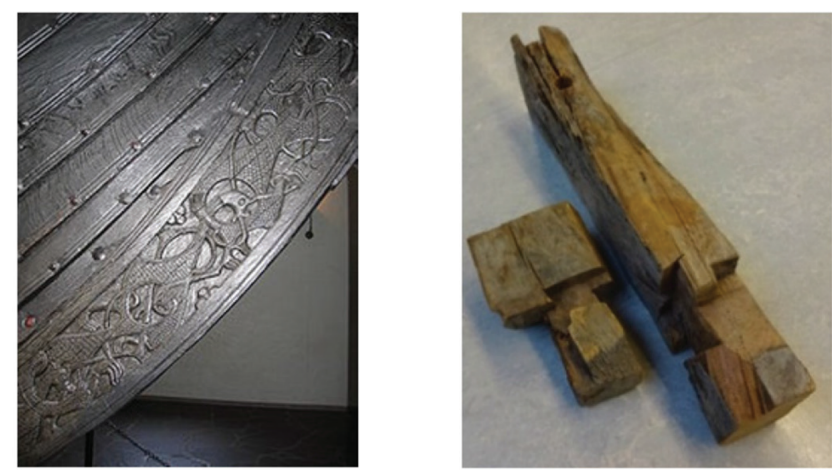

Figure 3: Cogged head. 


\section{THE COGGING TECHNIQUE}

One of the many experiences that the Vikings took home was cogged art. Most think that this was a construction technique that the Vikings discovered and brought home from Gardariket, i.e. from today's Russia, around the turn of the millennium. In Norway, for about 1000 years, until World War 2, the cogging technique was the most common method of building for homes and other buildings intended for private residence. Barns and stables, storehouses and outbuildings were also often built as log buildings. When a building technique remains virtually unchanged throughout such a long period of time, it means that it is suitable and good; otherwise, it would have been superseded by newer and better methods much sooner. What qualities made cogging that good? Briefly, two reasons: As previously mentioned, wood has good heatinsulating capacity. The effort to obtain a warm house in a cold Norwegian winter made timber the clear winner. The second is that wood is a hygroscopic material, living with humidity. When timber dries, it shrinks and when it becomes damp, it expands. If the timber is held vertically, cracks will rapidly appear between the logs, so the house is draughty and cold. However, if one adds the logs horizontally, gravity will ensure that the wall remains tight, even when the wood shrinks. Cogging is the wood building answer to the brick wall, starting horizontally and stacking the construction layer for layer. But stacking logs on top of each other, and getting them to be permanently stable in their proper place, is a challenging task that requires both theoretical knowledge and practical skills. Logs shrink, but they also twist and turn when they dry, and this is a particular problem in connection with openings for windows and doors. In the corners, the so-called log heads, half of the wood is removed; However one must not remove too much, because this will make openings; nor must one remove too little, because then there will be openings in the other direction. Figure 3 shows two cogged heads from a simple outhouse construction. We see that the logs are folded into one another in an intricate but thoughtful way, and we understand that, to create a tight corner, the carpenters had to have the ability to envision how the concave and convex log heads would fit together. It was common for log buildings to be left standing to dry for a year before they were completed and the doors and windows installed, and the buildings eventually cladded outside or inside. Perhaps the logs were marked and the structure dismantled and shipped, almost like an IKEA flat pack, to its destination: to the fire locations in Stavanger or another treeless area on the west coast, to northern Norway or above the tree line (Fig. 4).

\section{GRINDABYGG}

Before the notching technique with its horizontality came into use, the starting principle for structures was the vertical. A common construction principle was called gates: i.e. two pillars connected by a crossbar, much like a soccer goal. Figures 5 and $6 \mathrm{a}$ and $6 \mathrm{~b}$ show a

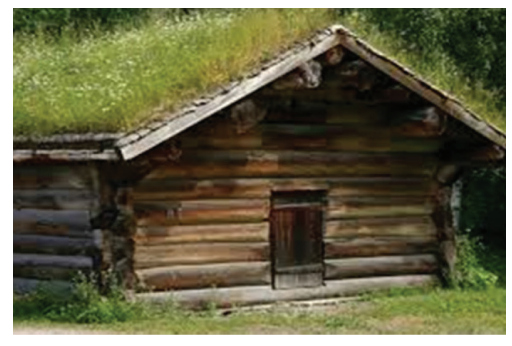

Figure 4: Old cogged house.

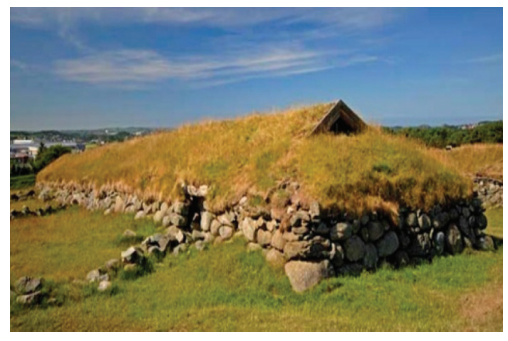

Figure 5: The Iron Age house near Stavanger University. 


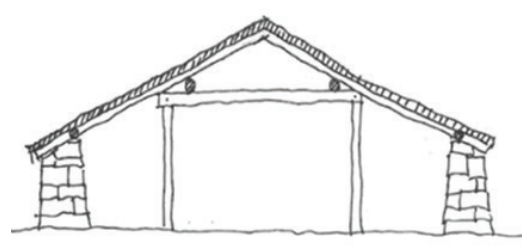

Figure 6 ( $a$ and b): Section of Iron Age house.

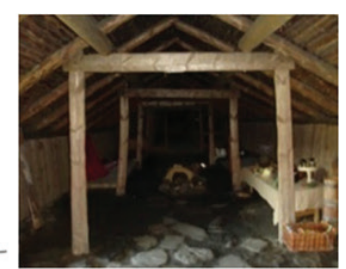

(n)

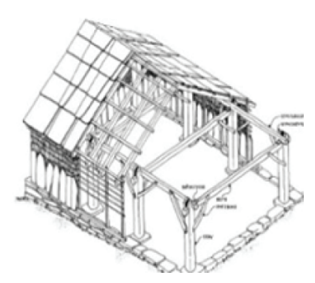

Figure 7: Principle of grindabygg.

reconstructed farmstead from the Iron Age near the University of Stavanger. Figure 7 shows a so-called grindahus ('a gate house'), a further development of the Iron Age building that was normal for outbuildings along the Norwegian west coast right up to the interwar period [4].

\section{THE STAVE CHURCHES}

Stave churches are an evolution of the gate principle. In the Middle Ages, most Norwegian churches was built of wood, and practically all wooden churches were built in a supporting structure of poles (staver). The construction principle gives the name to the church type. The poles are placed on sills (syllstokker) and carry the crossbar. The constructive joints in the wall form frames with a padding of standing planks (tiler) (Fig. 8). Most stave churches were built in the years 1150-1350, i.e. over a period of as long as 200 years. Throughout such a long time, many changes occur in a society, of a technical-economic nature, in belief and style preferences. The stave churches remaining today therefore differ from each other in many ways. It is usual to divide them into two main groups: one-nave churches and churches with a raised center. In several works on the subject, we find that the stave churches are compared with the Roman basilicas. For example, L. Dietrichson in his book, The Norwegian Stave Churches (1892) stated that the stave church is: 'an ingenious translation of the Romanesque basilica from stone to wood' [5]. I do not agree with this so-called 'basilica theory'. Norway had connections with the Pope in Rome who led the Christian world at the time. In this period, 1150-1350, churches in Europe were built in the Gothic style. Therefore, I would rather say that the stave church is a brilliant translation of the stone gothic cathedral into wood (Fig. 9 \& 10).

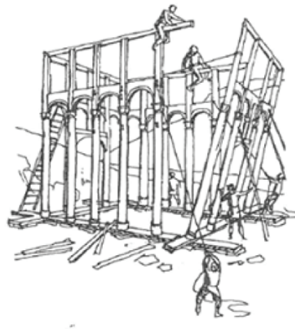

Figure 8: Stave church, construction principle.

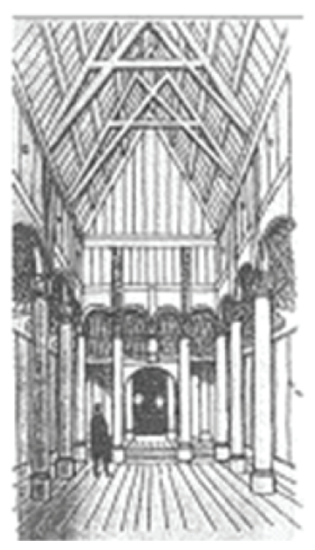

Figure 9: Stave church interior.

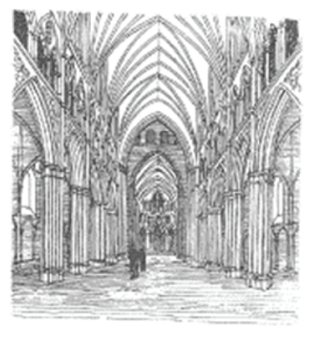

Figure 10: Gothic cathedral interior. 
The Gothic style turned away from the heavy, brick, full-center vault to slim pointed arches that rise into the sky. It is the same aspiration that we find successfully brought to fruition in the vertical, towering of the stave churches, especially the stave churches with raised center. Each Gothic cathedral or stave church has its own individual feeling, but I think that many people share my perception that, despite their differences, when you enter them, the rooms speak to one with the same spirit (Figs. 11-13).

Stave churches are adorned with carving of an impressive craftsmanship, and we realize that we are dealing with artists who have roots in a longstanding tradition of high quality work. Dragons and scrolled plant ornaments call to mind the Gothic cathedral ornaments and grotesque gargoyle (water dragons) and Viking ships too, with their decorative techniques and motifs from pre-Christian times. We find much of the same insightful skill and understanding of material in the construction of both Viking ships and stave churches. Both combine elasticity and strength. Moreover, the stave church construction encapsulates the points that should not be exposed to moisture and rot. Both Viking ships and stave churches are excellent results arising out of a culture that 'knows' wood. (Figs. 14-16)

In the middle Ages, there were probably over 1000 stave churches in Norway. Only 28 of these are still standing, most having disappeared between 1350 and 1650 . The stave churches are considered to be among the most important representatives from the Middle Ages of European architecture in wood, and constitute perhaps the most important Norwegian contribution to world architectural heritage [5].

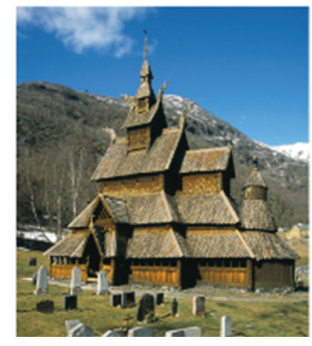

Figure 11: Borgund stave church.

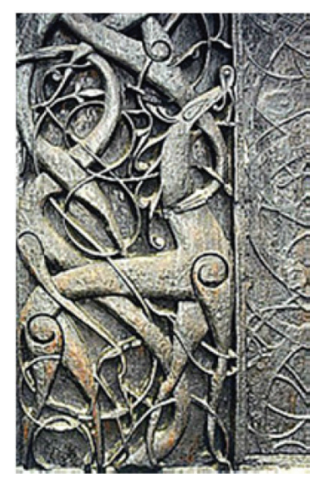

Figure 14: Urnes stave church, segment of the portal.

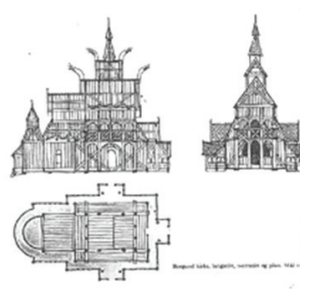

Figure 12: Borgund stave church, drawings.

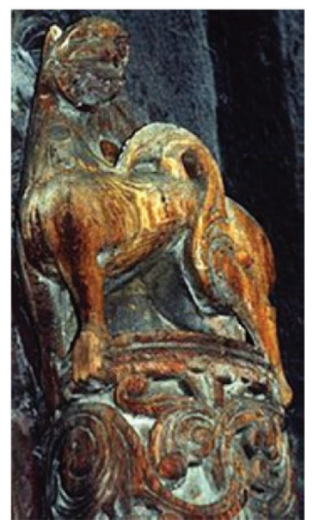

Figure 15: Borgund stave church, lion decoration.

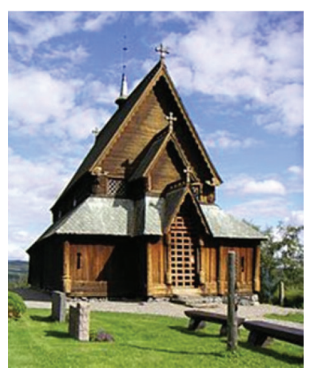

Figure 13: Hedalen stave church.

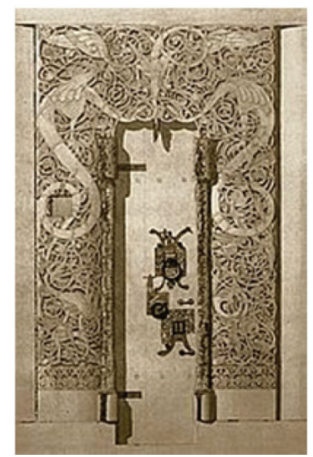

Figure 16: Heddal stave church, portal decoration. 


\section{RENAISSANCE AND BAROQUE}

After the loss of independence and the Black Death, the recession began to turn around in 1550 , but it took another half century before the recovery became evident. The Churches in Norway books (6 volumes, 1620 pages) [6] presents 73 churches before the Black Death and 175 churches built after 1600, but only one single built in the 250 years between 1350 and 1600 - a small stave church raised in a small fishing village on Grip, an island far out at sea, probably in 1470 . We see the same pattern for all types of buildings: they built very little, and what they did build was constructed as was customary before the Black Death.

The Reformation took place in Denmark-Norway in 1537, and it is common to use this year as marking the end of the Middle Ages in Norway.

It took 150 years for the Renaissance style, which originated in Italy around 1400, to arrive in Norway around 1550. By then, southern Europe had already started to build in the Baroque style. However, construction of new Protestant churches did not start until 1600, and then the time of the stave churches was over. Most churches were now constructed by means of the cogging technic: firstly, in the Renaissance style and then gradually more and more clearly Baroque. Stone does not have a given form initially. Natural stone must be cut, and clay must be formed and fired into bricks before actual construction can begin. The manufacturing and construction processes therefore do not matter much in respect of making the stones or the walls plane or curved. Logs, however, have a straight trunk, and thick trunks cannot bend. This is appropriate for the Renaissance style, which is largely based on clear geometrical shapes with tight, straight walls (Figs. 17-19).

The Baroque style, however, is characterized by a strong emphasis on the architectural space with a powerful plastic processing of both the major surfaces and he details. In Baroque masterpieces, we see that both facades and interior walls alternate between convex and concave surfaces, in both the construction and the details [6]. It is difficult to translate this modulation into log work. Admittedly, towards the end of the 1700 s, they did build some eight-angled churches. It is easy to construct an eight-sided building in a log technique, and an eight-edged room is essentially circular, dynamic and baroque. However, cogging has a structural logic and horizontal character that is still the dominant impression. It is difficult to distinguish churches listed between 1600 and 1850 on the basis of construction, layout and main form. Renaissance, Baroque, Rococo and Empire mostly provide the same constructive shell. The style impulses from Europe's stone buildings are found to a greater extent in the decoration of the surfaces, especially in interiors, but also outside. Inside, this applies not least to the use of the acanthus motifs, which were known from antiquity but received renewed

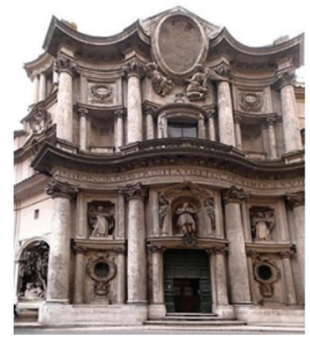

Figure 17: The idea of Barocque.

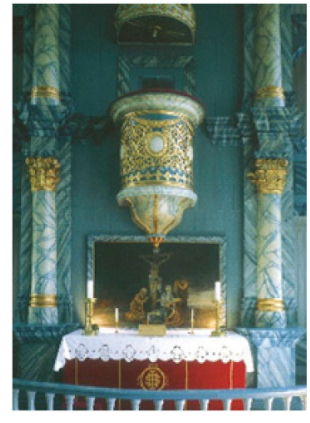

Figure 18: Tynset ch. Marmorate columns.

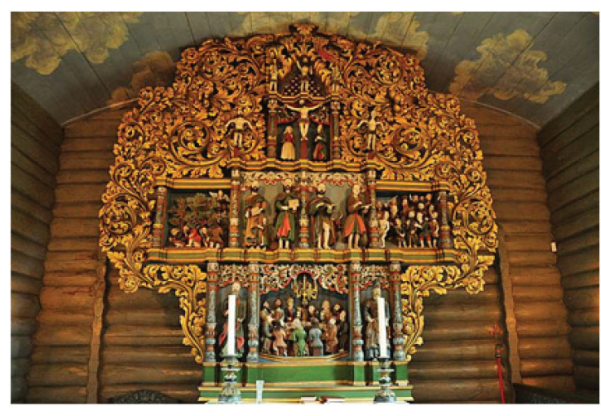

Figure 19: Lesja churchAcanthus carving. 


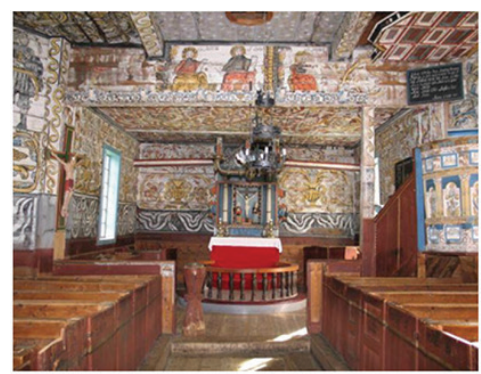

Figure 20: Stordal old church Rose painting.

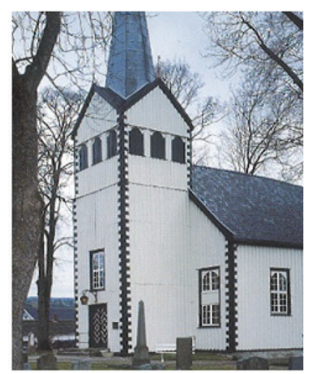

Figure 21: Imitation hewn stone, West Porsgrunn ch.

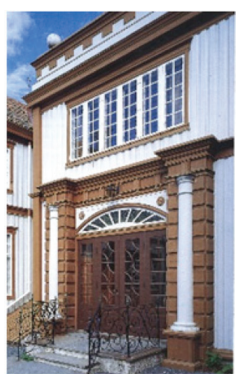

Figure 22: Leangen Imitated hewn stone.

interest in the Renaissance era and reached their climax during the Baroque period. Acanthus decorations secured a fast foothold in Norway, both as woodcarvings and as a painted finish. The woodcarving was a continuation of the craftsmanship tradition of the Viking ships and the ornamentation of the stave churches, while the acanthus in a painted finish was the starting point for our popular folk art, rose paintings (Fig. 20). We also see that the European role models in stone were being copied by so-called marbling; the wall surfaces and columns being painted to look as if they were marble. Another, mainly exterior painting technique, is to paint the corners with imitated hewn stone [7] (Figs. $21 \& 22$ ).

\section{THE SWISS STYLE}

In the latter half of the 1800 s, Norwegian society was strongly influenced by national romantic currents. The artists sought 'the Norwegian' within literature, painting, music, etc. We find the same tendency in many European countries at this time, but the impact was perhaps particularly strong in Norway. For nearly 500 years under Danish rule and then 50 years under Swedish rule, the intellectual elite was strongly committed to building the nation. Cultural life helped

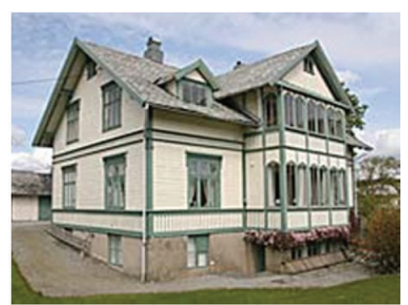

Figure 23: The Swiss Style (1880-1920).
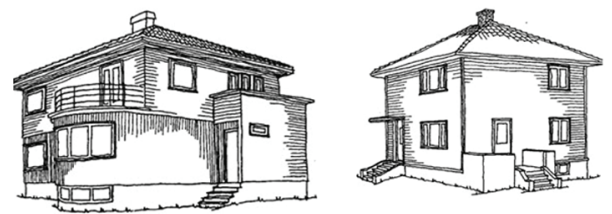

Figure 25: Norwegian functionalism in wood.

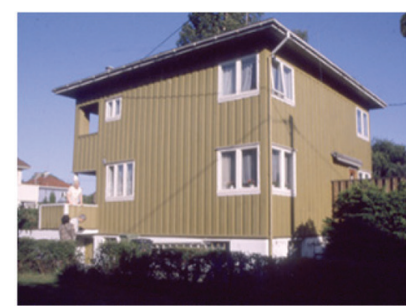

Figure 24: Functionalism in wood (1930-1940).

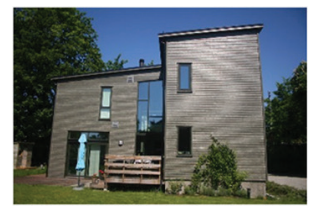

Figure 26: 'Modern' functionalism. 
to create an awareness of Norwegian values and mobilized a national confidence that ultimately led to Norway becoming an independent nation in 1905. In architecture, the historicism (neo-gothic, neoclassicism, neo-baroque, etc.) was the prevailing style direction, and many argued that one should find an architectural style with a national character, instead of the old styles of foreign origin. This also happened: the Swiss Style! (Figs. 23).

This name is actually a misconception, for Swiss Style is a Norwegian architectural style, which is not found in Switzerland, although the architects derived some inspiration from Switzerland - including large eaves and decoration - but especially from the fact that, in Switzerland, the national architectural style is in wood. The Swiss Style quickly became immensely popular and still sets its strong mark on residential buildings in both town and country. Many houses are still built as Swiss Style imitations. Residential buildings in Norway are largely small houses, and 99\% of small houses are in wood. However, we are now talking about From Swiss Wood to Norwegian Wood, which is partially outside the lecture title.

\section{FUNCTIONALISM}

However, when it comes to functionalism, it is certainly appropriate to say 'From Stone to Norwegian Wood'. The technical premise of functionalism was reinforced concrete and the opportunities that this new material created. In earlier times, it took many years before the continental style trends came into use in Norway, but this changed when it came to functionalism. Norway and Sweden were among the first countries where this new style early established itself in a certain scope. The first functionalist signature buildings were, correctly enough, built in concrete, but the style quickly became popular, and small houses in the functionalist style quickly became common all over the country, and, in the last 10-15 years, wooden houses with functionalist ideals have again become popular (Figs. 24-26).

\section{CONTEMPORARY NORWEGIAN WOODEN ARCHITECTURE}

Finally, I will show some examples of contemporary Norwegian wooden architecture [8]. The traditional motivation to build in wood - climate, economics, knowledge and tradition - apply today to a lesser extent than previously. Today, I rather choose the key words: sustainability, innovation and architectural character.

- Sustainability: Wood binds $\mathrm{CO}_{2}$, and the manufacturing requires little energy. It is a local material and requires little transport, and it can be sensibly reused. In all the environmental accounting, it is significantly better than alternative construction materials in concrete, brick and steel.

- Innovation: The old carpenters die, and much of the traditional wood knowhow has already passed into oblivion. However, at the same time, the use of wood has passed from being a handcraft to becoming an industry, and these days there happens to be a rapid development of production methods and products: for example, solid wood, large glulam structures and new forms of wood with great rot resistance. Many architects find this development exciting.

- Architectural character: The Winter Olympics at Lillehammer in 1994 mark a turning point, in many ways. Norway wanted to present its national qualities in a convincing manner and, within architecture, wood was an expression of something typically Norwegian, an important marker. The main wood projects were the major sports halls Viking Ship and Christins Hall, and the main roof construction in the airport at Gardermoen. Among architects, this created awareness that wood offered opportunities that they might not have been conscious of before, and since then many innovative projects have seen the light of day. 


\subsection{The Tree}

The 'Tree' was built in 2015, and took the lead as the world's tallest wooden building. It is an apartment building located on the seafront in Damsgardssundet in Bergen. The house is 14 stories high and built with a combination of several modules, glulam structures and crosslaminated timber. The main supporting structure consists of vertically oriented laminated timber trusses with platforms in concrete in the 5th, 10th and 14th floor. (Architect: ARTEC AS, project period: 2012-2015, area consumption: $3780 \mathrm{~m}^{2}$, Fig. 27).

\subsection{Oslo Airport}

In Oslo Airport a new pier is under construction. This new pier will be about 300 meters long, $63.000 \mathrm{~m}^{2}$ and have a roof cladded with oak from sorted heartwood. The supporting structures of the pier will consist of glulam. Its shape makes it possible to take advantage of passive solar energy and sunlight, as well as having district heating and natural thermal energy. (Project completion: 2017, architect: Nordic, Fig. 28).

\subsection{Da Vinci Bridge}

The artist, Vebjørn Sand, had the idea to build a Leonardo da Vinci bridge. The bridge was originally designed by da Vinci in 1502, 240 meters long and supposed to cross The Golden Horn, but it was never built. The bridge in Ås was made after Leonardo da Vinci's original drawings but reduced to 108 meters and built in wood glulam, not in stone. On top of the

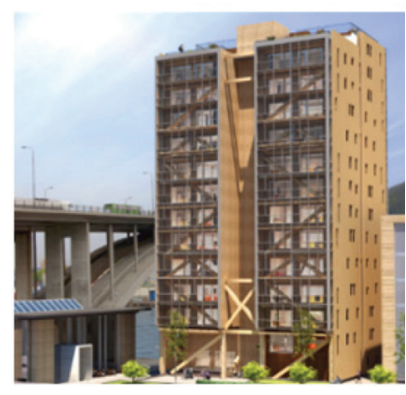

Figure 27: Treet, Bergen, 14 stores.

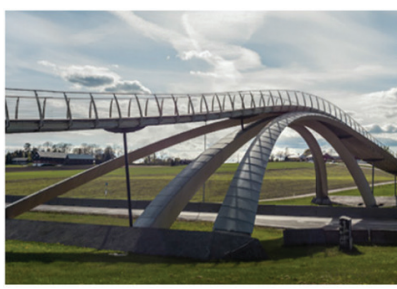

Figure 29: The da Vinci bridge, Ås, (2001).

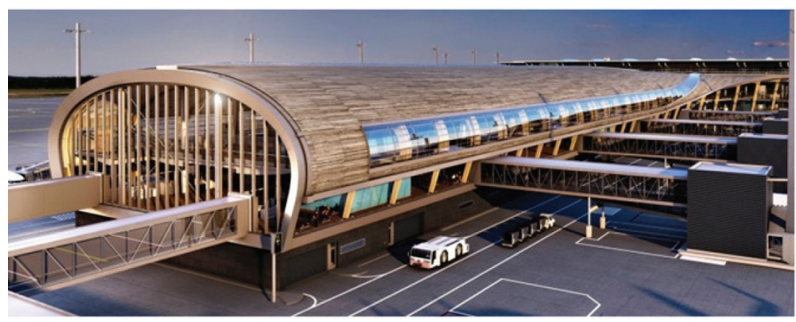

Figure 28: Oslo Airport, new pier.

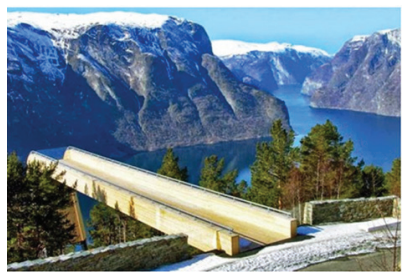

Figure 30: Stegastein viewpoint. 
glulam girders is the pedestrian deck, on which you can walk or cycle. (Architect: Selberg Arkitekter, project completion: 2001, height: 10m, Fig. 29).

\subsection{Stegastein}

The Stegastein viewing platform is open all year round and situated along the mountain road between Aurland and Lærdal. The platform hangs 30 meters out from the mountain walls and 650 meters up from the fjord and gives you the feeling that you are floating above the fjord and villages below. There is a splendid panoramic view of the fjord and a unique closeness to nature. The platform is light, dynamic and floating. It is 4 meters wide and 30 meters long, built in laminated wood and steel with a thick glass plate at the end. (Architect: Todd Saunders and Tommie Wilhelmsen, project completion: 2006, Fig. 30).

\section{CONCLUSION}

Virtually everything that can be built in stone can also be built in wood. However, one should take into account that wood is different from stone-like, hard materials, and the Norwegians have always done this. This article has shown different methods of such transformation. If this is done skillfully, it will never be a matter of pure copying. The reasons for the Norwegians building so much with wood can be summarized with the keywords: climate, economy, knowledge and tradition.

Today there is a renewed interest in wood as a building material among Norwegian architects because it is sustainable, it is the subject of an interesting technical development and it is an exciting and vibrant material to work with.

\section{REFERENSES}

[1] Christensen, A.L., Den norske byggeskikken, Pax Forlag: Oslo, pp. 44-51, 1995.

[2] Haaland, A., En by tar form, Wigestrands forlag: Stavanger, pp. 127-163, 1999.

[3] Accessed on: https://no.wikipedia.org/wiki/Murtvang

[4] Brekke, N.G. \& Schjelderup, H., Hus på vestkysten gjennom 4000 år, Fortidsminneforeningen: Bergen/ Stavanger, pp. 18-29, 1997

[5] Ekroll, Ø., et al., Kirker i Norge, volume 1-6, Arfo: Oslo, 2000-2008.

[6] Thiis Evensen, T., Europas Arkitekthistorie - fra idé til form, Gyldendal, Oslo, pp. 98-114, 1995.

[7] Brænne, J., Dekorasjonsmaling. Teknologisk forlag: Oslo, pp. 85-122, 1998.

[8] Olsen, M., Norwegian Wood, unpublished, UiS, 2016. 